\title{
Aplikasi Sistem Pendukung Keputusan Distribusi Air Bersih dengan Fuzzy Integer Transportation
}

\author{
A. Arifin dan S. Hartati
}

\begin{abstract}
Abstrak- Kebutuhan air bersih di kota-kota berkategori urban semakin lama semakin meningkat, sementara produktivitas air menurun disebabkan oleh berbagai alasan. Persoalan yang harus dipecahkan adalah bagaimana agar distribusi air ke tujuan berjalan secara simultan, yakni antara supply air dengan demand pelanggan ditengah minimnya anggaran biaya. Perlu dicari keputusan bagi perencanaan distribusi yang baik untuk mengalokasikan air, dari sejumlah sumber air menuju sejumlah tujuan (kota). Oleh karena itu, diperlukan sistem terkomputerisasi yang memiliki kemampuan dalam memberikan dukungan untuk pengambilan keputusan, maka perlu dirancang suatu sistem pendukung keputusan (SPK) yang dapat membantu manajemen distribusi air bersih. SPK ini mengimplementasikan Fuzzy Integer Transportation dengan nilai fuzzy supply, fuzzy demand dan fuzzy goal yang diekspresikan melalui bilangan fuzzy. Tabel transportasi dipakai untuk mempermudah pemodelan nilai supply dan demand yang ber-interval. Sebuah algoritma khusus digunakan agar dapat menghasilkan solusi integer yang optimal sehingga dapat meningkatkan efisiensi pencarian. Selain itu pemecahan masalah distribusi ini memakai pendekatan Vogel's Approximation Method (VAM), memberikan solusi yang feasible bagi total biaya distribusi. Output sistem adalah total biaya distribusi dan jumlah air yang didistribusikan ke masing-masing tujuan.
\end{abstract}

Kata Kunci-Sistem Pendukung Keputusan, Fuzzy Integer Transportation, VAM

\section{PENDAhUluan}

$\mathrm{D}$ istribusi air berhubungan dengan ketersedian air dan produksinya (supply) serta permintaan air oleh konsumen (demand). Distribusi air merupakan kelanjutan dari proses produksi air, dimana kemudian air bersih disalurkan ke masyarakat. Tanggung jawab penyediaan dan distribusi air bersih pada kategori urban ada di PDAM [1]. Urban merupakan kota dengan standar kebutuhan air bersihnya adalah di atas 100 liter per orang [2].

Aridhanyati Arifin, Program Studi S2 Ilmu Komputer, Fakultas Matematika \& Ilmu Pengetahuan Alam, UGM, Yogyakarta, email: aridhanyati@yahoo.com

Sri Hartati, Departemen Ilmu Komputer dan Elektronika, Fakultas Matematika \& Ilmu Pengetahuan Alam, UGM, Yogyakarta, Sekip Utara PO BOX BLS.21 Yogyakarta 55281, e-mail : shartati@ugm.ac.id
Kebutuhan air bersih di kota-kota urban semakin lama semakin meningkat yang berhadapan dengan masalah produksi air menurun berhubung produksi sumur dalam yang menurun, degradasi lingkungan, perubahan tata kota yang mengurangi debit produksi, kurangnya perawatan (maintenance) serta keterbatasan anggaran dan sarana/prasarana. Persoalan yang harus dipecahkan adalah bagaimana agar distribusi air ke tujuan berjalan secara simultan, yakni antara supply air dengan demand pelanggan ditengah minimnya anggaran biaya.

Scoot Morton pada tahun 1970-an menyebutkan dalam Turban \& Aronson, bahwa SPK adalah sistem berbasis komputer interaktif yang membantu para pengambil keputusan untuk menggunakan data dan berbagai model untuk memecahkan masalah tidak terstruktur[3]. Sistem dibagi atas 3 bagian yaitu input, proses dan output, seperti yang ditunjukkan gambar 1 .

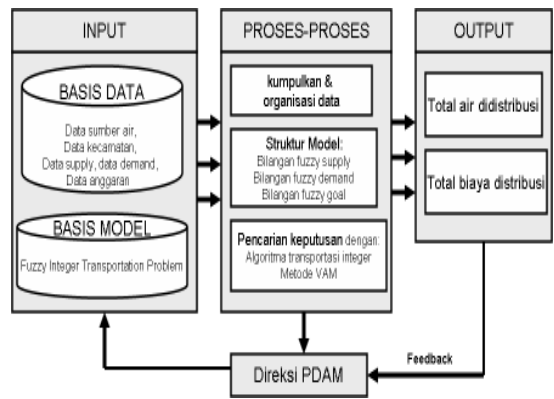

Gambar 1 Skema struktur sistem

Sistem Pendukung Keputusan distribusi air bersih dibangun atas beberapa subsistem seperti yang ditunjukkan dalam gambar 2 .

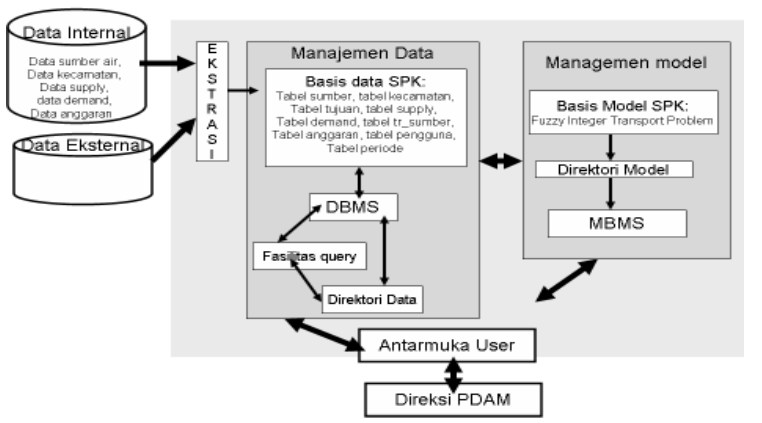

Gambar 2 Komponen SPK

Masalah manajemen distribusi pada beragam topik telah banyak diselesaikan dengan memakai 
teknologi Sistem Pendukung Keputusan (SPK) mengingat perencanaan distribusi adalah hal yang kompleks dan rumit bagi seorang pembuat keputusan bila menggunakan metode klasik mengingat keterbatasan data yang ada. Perencanaan keputusan untuk distribusi membutuhkan pertimbangan-pertimbangan yang terukur, tidak sebatas intuisi pembuat keputusan.

Implementasi teknologi SPK pada topik manajemen distribusi air, adalah Raman, dkk [4]. menjelaskan pemanfaatan SPK untuk mengemulasi dan meningkatkan kemampuan perencanaan distribusi air dalam proses pembuatan keputusan pada studi kasus di India Selatan menggunakan pendekatan berbasis pengetahuan. Soehadi [5] dalam penelitiannya menggunakan teknologi SPK untuk optimisasi penyaluran air sebagai bagian dari manajemen irigasi. Masalah distribusi sebenarnya merupakan masalah transportasi. Dalam penelitiannya Ozceylan [6] menjelaskan penggunaan teknologi SPK untuk optimasi pemilihan mode transportasi

Ciri khas dari SPK adalah terdapatnya minimal satu model dalam penyelesaian masalah untuk mendukung keputusan. Model transportasi hadir untuk mempertemukan supply dan demand yang biasanya bertujuan untuk meminimalkan biaya total transportasi, namun juga terdapat tujuan lain seperti meminimalkan waktu distribusi atau memaksimalkan keuntungan. masalah transportasi banyak hadir dalam nilainilai yang tidak dapat ditentukan secara pasti atau bersifat kabur (fuzzy). Terdapat beberapa penelitian yang telah dilakukan untuk perencanaan keputusan dalam masalah fuzzy transportasi yang menawarkan beberapa metode untuk memecahkan masalah transportasi ini serta memberikan alternatif solusi bagi pengambilan keputusan seperti metode linier programming [7], Interactive fuzzy multiobjective linier Programming (i-FMOLP) [8], Fuzzy Monte Carlo [9], Lexicographic Goal Programming (LGP) [10] dan penerapan Fuzzy Integer Transportation digunakan pada masalah distribusi air di PDAM Surakarta [11]

Dalam makalah ini, masalah distribusi air adalah masalah fuzzy transportasi yang dimodelkan dengan fuzzy integer transportation. Adapun total supply air direpresentasikan ke bentuk bilangan fuzzy supply, sedangkan total demand air direpresentasikan ke bentuk bilangan fuzzy demand dan dana distribusi dimodelkan dengan bilangan fuzzy goal. Algoritma transportasi integer dipakai untuk memecahkan masalah fuzzy integer transportation ini dengan memanfaatkan pendekatan VAM untuk mencari solusi basis awal yang feasible.

Fokus makalah ini adalah merancang bangun aplikasi sistem pendukung keputusan distribusi air dengan mengimplementasikan fuzzy integer transportation untuk merencanakan distribusi air agar kebutuhan air pelanggan mendekati harapan dengan biaya distribusi yang minimum.

\section{FUZZY INTEGER TRANSPORTATION}

Fuzzy Integer Transportation merupakan pengembangan dari model transportasi klasik. Hanya saja, dalam aplikasinya parameterparameternya bersifat tidak pasti atau mengandung nilai samar. Fungsi tujuan (objective function) dan batasan-batasan (constraint) direpresentasikan dalam bentuk bilangan fuzzy, parameter-parameter transportasi diformulasikan secara linier seperti yang ditampilkan pada kaidah (1) dan kaidah (2). Selain itu pada Fuzzy Integer Transportation seluruh variabel keputusan bernilai integer. Formulasi Fuzzy Integer Transportation [12] :

$c(x)=\sum_{i=1}^{m} \sum_{j=1}^{n} c_{i j} x_{i j} \rightarrow \min$

Dengan batasan sebagai berikut:

$$
\begin{aligned}
& \sum_{i=1}^{m} X_{i j} \cong A_{i} ; i=1,2, \ldots, m \\
& \sum_{j=1}^{n} X_{i j} \cong B_{j} ; j=1,2, \ldots, n
\end{aligned}
$$

Keterangan:

$c(x)$ total biaya distribusi

$c_{i j} \quad$ biaya transmisi \& distribusi per unit dari sumber $i$ ke tujuan $j$

$x_{i j} \quad$ jumlah air yang akan dikirimkan dari sumber

$i$ ke tujuan $j$

$A_{i} \quad$ jumlah supply di sumber $i$

$B_{j} \quad$ jumlah demand di tujuan $j$

$A_{i}, B_{j}$ bilangan fuzzy

$x_{i j} \geq 0$, integer

$A_{i}$ dan $B_{j}$ adalah bilangan fuzzy yang

mengikuti bentuk:

$$
\begin{gathered}
A_{i}=\left(\underline{a_{i}}, \bar{a}_{i}, \alpha_{A_{i}}, \beta_{A_{i}}\right)_{L-L} \\
B_{j}=\left(\underline{b_{j}}, \bar{b}_{j}, \alpha_{B j}, \beta_{B_{j}}\right)_{L-L}
\end{gathered}
$$

Dengan :

$\underline{a}_{i} \quad$ nilai tengah batas atas pada supply di sumber $i$

$\bar{a}_{i} \quad$ nilai tengah batas bawah pada supply di sumber $i$ 
$\underline{b}_{j} \quad$ nilai tengah batas atas pada demand di tujuan $j$

$\overline{b_{j}} \quad$ nilai tengah batas bawah pada demand di tujuan $j$

$\alpha_{A i}$ selisih nilai tengah batas bawah dengan nilai minimum (kiri) pada supply di sumber $i$

$\beta_{A i}$ selisih nilai tengah batas atas dengan nilai kanan pada supply di sumber $i$

$\alpha_{B j}$ selisih nilai tengah batas bawah dengan nilai kiri pada demand di tujuan $j$

$\beta_{B j}$ selisih nilai tengah batas atas dengan nilai maksimum pada demand di tujuan $j$

Fungsi keanggotaan untuk model tujuan yang diekspresikan bilangan fuzzy yang dinotasikan oleh $G$ adalah:

$$
G=\left(0, c_{0}, 0, \beta_{G}\right)_{L-L}
$$

Keterangan:

$$
\begin{array}{ll}
c_{0} & \begin{array}{l}
\text { anggaran dana yang tersedia untuk } \\
\text { transportasi }
\end{array} \\
\beta_{G} & \begin{array}{l}
\text { selisih antara anggaran dana transportasi } \\
\text { yang tersedia dengan dana transportasi } \\
\text { cadangan } \\
\text { fungsi linier }
\end{array}
\end{array}
$$

Terdapat beberapa definisi yang memperjelas bagaimana kecocokan batasan-batasan fuzzy (fuzzy constraints) dan kecocokan fuzzy goal dapat dipahami pada kaidah (1), sebagai acuan mencari solusi $x$, yaitu:

\section{Definisi (1) :}

Misalnya $x$ untuk sembarang penyelesaian maka nilai persamaan (1), disebut sebagai derajat kecocokan batasan untuk persamaan (1) dan nilai persamaan (1) disebut sebagai derajat kecocokan goal dari persamaan (1)

$$
\begin{aligned}
& \mu_{c}(x)=\min \left\{\mu_{A_{i}}\left(\sum_{j=1}^{n} x_{i j}\right)(i=1, \ldots, m), \mu_{B_{j}}\left(\sum_{i=1}^{m} x_{i j}\right)(j=1, \ldots, n)\right\} \\
& \mu_{G}(x)=\mu_{G}(c(x))=\mu_{G}\left(\sum_{i=1}^{m} \sum_{j=1}^{n} c_{i j} x_{i j}\right) \\
& \text { Keterangan: }
\end{aligned}
$$

Keterangan:

$$
\begin{array}{ll}
\mu_{c}(x) & \text { derajat kecocokan batasan } \\
\mu_{A_{i}} & \text { derajat keanggotaan supply } \\
\mu_{B_{j}} & \text { derajat keanggotaan demand }
\end{array}
$$

Definisi (2): Solusi maksimum dari kaidah (1) adalah $x$, yang mana fungsi pada kaidah (5) mengandung nilai maksimum. Apabila nilai maksimumnya adalah nol, maka kaidah (1) dinyatakan berada dalam kawasan infeasible.

$$
\mu_{D}(x)=\min \left\{\mu_{c}(x), \mu_{G}(x)\right\}
$$

Keterangan:

$$
\begin{array}{ll}
\mu_{G}(x) & \text { derajat kecocokan goal } \\
\mu_{D}(x) & \text { solusi maksimum }
\end{array}
$$

Chanas dan Kuchta memaparkan beberapa definisi untuk penyelesaian masalah fuzzy transportasi, yakni:

\section{Definisi (3) :}

Misalnya A adalah bilangan fuzzy, $\lambda$-cut dari $A$ dinotasikan dengan $A^{\lambda}$, yang merupakan himpunan bilangan real, dengan nilai fungsi keanggotaan A tidak lebih dari $\lambda$, dengan bentuk seperti berikut ini:

$$
\begin{aligned}
& A^{\lambda}=\left\{t \in R \mid \mu_{A}(t) \geq \lambda\right\} \\
& \text { Dengan asumsi } A_{i} \text { dan } B_{j}, \text { maka }
\end{aligned}
$$
$\lambda-$ cut $A_{i}^{\lambda}$ dan $B_{j}^{\lambda}$ adalah interval dari bentuk berikut ini:

$A_{i}^{\lambda}=\left[\underline{a_{i}}-{ }^{-1}(\lambda) \alpha_{A i}, \bar{a}_{i}+{ }_{L}^{-1}(\lambda) \beta_{A i}\right] ; i=1,2, \ldots, m$

$B_{j}^{\lambda}=\left[b_{j}-L_{j}^{-1}(\lambda) \alpha_{B j}, \bar{b}_{j}+\stackrel{L}{j}_{j}^{-1}(\lambda) \beta_{B j}\right] ; j=1,2, \ldots, n$

adalah:

Dimana $\lambda$-cut dari fuzzy goal $\mathrm{G}$

$G^{\lambda}=\left[0, c_{0}+L_{G}^{-1}(\lambda) \beta_{G}\right]$

Kaidah (1) dapat ditulis kembali dengan memuat nilai $A_{i}$ dan $B_{j}$ dari kaidah (6) menggunakan cara-cara berikut ini

$$
\begin{aligned}
& \lambda \rightarrow \text { maks } \\
& c(x) \in G^{\lambda} \\
& \sum_{i=1}^{n} X_{i j} \in A_{i}^{\lambda} ; i=1,2, \ldots, m \\
& \sum_{j=1}^{m} X_{i j} \in B_{j}^{\lambda} ; j=1,2, \ldots, n
\end{aligned}
$$

Kaidah (8) dibawa ke masalah transportasi interval (9) yang telah memiliki nilai integer di dalam nilai interval demand dan supply -nya tanpa mengubah solusi optimal dan kondisi feasible, seperti yang termuat dalam definisi (4) di bawah ini.

\section{Definisi (4):}

Misalkan A adalah sembarang interval, simbol [A] menotasikan interval terbesar yang memiliki nilai integer, misalkan $[A]=[a, b]$, dimana:

$$
\begin{aligned}
& \mathrm{a}=\min \{\mathrm{t} \mid \mathrm{t} \in \mathrm{A}, \mathrm{t} \text { integer }\}, \\
& \mathrm{b}=\max \{\mathrm{t} \mid \mathrm{t} \in \mathrm{A}, \mathrm{t} \text { integer }\}
\end{aligned}
$$


Keterangan:

$$
\begin{aligned}
& c(x) \rightarrow \min , \\
& \sum_{j=1}^{n} x_{i j} \in\left[A_{i}^{\lambda}\right], i=1, \ldots, m \\
& \sum_{i=1}^{m} x_{i j} \in\left[B_{j}^{\lambda}\right], j=1, . ., n
\end{aligned}
$$

$\left[A_{i}^{\lambda}\right]$ Nilai interval $\lambda-c u t$ dari jumlah supply di sumber $i\left(A_{i}\right)$

$\left[B_{j}^{\lambda}\right] \quad$ Nilai interval $\lambda-c u t$ dari jumlah demand di tujuan $j\left(B_{j}\right)$

$x_{i j} \geq 0$, dan integer

Disarankan dalam setiap langkah algoritma memakai nilai berinterval $\left[\lambda_{1}, \lambda_{2}\right]$ seperti masalah pada kaidah (8) adalah feasible untuk $\lambda=\lambda_{1}$ dan infeasible untuk $\lambda=\lambda_{2}$, sebagaimana yang didefinisikan pada defenisi (5).

\section{Definisi (5).}

Jika pada masalah (8) terdapat nilai $\lambda=\lambda_{1}$ yang identik dengan nilai $\lambda=\lambda^{*}$ maka nilai $\lambda=\lambda_{1}$ adalah minimal extension dari nilai $\lambda=\lambda_{2}$, dimana:

$\lambda^{*}=\max \left\{\max _{1 \leq i \leq m, t \notin A_{j}^{\lambda}} \mu_{A_{i}}(t), \max _{i \leq j \leq n, t \notin B_{j}^{\lambda}} \mu_{B_{j}}(t)\right\}$ Dengan $\mathrm{t}=$ integer.

Dilakukan transformasi dari transportasi interval menuju transportasi klasik sehingga algoritma transportasi dapat digunakan untuk menyelesaikan masalah fuzzy transportasi, adalah sebagai berikut:

1. Misalnya terdapat suatu masalah transportasi dengan nilai supply dan demand yang berbentuk interval, berikut ini:

Minimumkan total biaya distribusi $c(x)$

$$
c(x)=\sum_{i=1}^{m} \sum_{j=1}^{n} c_{i j} x_{i j}
$$

Dengan batasan bernilai interval :

$$
\begin{aligned}
& \sum_{j=1}^{n} x_{i j} \in\left[a_{i}^{1}, a_{i}^{2}\right], i=1, \ldots, m \\
& \sum_{i=1}^{m} x_{i j} \in\left[b_{j}^{1}, b_{j}^{2}\right], j=1, \ldots, n
\end{aligned}
$$

Keterangan:

$a_{i}^{1}$ nilai supply batas atas pada interval di sumber $i$

$a_{i}^{2}$ nilai supply batas bawah pada interval di sumber $i$ $b_{j}^{1}$ nilai demand batas atas pada interval di tujuan $j$

$b_{j}^{2}$ nilai demand batas bawah pada interval di tujuan $j$ $x_{i j} \geq 0$, dan integer

2. Berhubung kaidah (9) berada dalam bentuk transportasi interval, maka kaidah tersebut akan diubah ke bentuk transportasi klasik dengan menambahkan nilai dummy pada sumber dan tujuan. Oleh karena itu diperoleh nilai supply fiktif yang memiliki sumber $2 m+1$ dan nilai supply $a_{i}=1, \ldots, 2 m+1$, mengikuti kaidah (10) berikut ini:

$$
\begin{aligned}
& a_{i}=a_{i}^{1} \quad ; \quad i=1,2, \ldots, m \\
& a_{i}=a_{i-m}^{2}-a_{i-m}^{1} ; \mathrm{i}=m+1, m+2, . .2 m \\
& a_{2 m+i}=\sum_{j=1}^{n}\left(b_{j}^{2}-b_{j}^{1}\right)
\end{aligned}
$$

3. Masalah transportasi klasik dengan tujuan $2 n+1$ dan nilai demand $b_{j}=1, \ldots, 2 m+1$, mengikuti kaidah (11):

$$
\begin{aligned}
& b_{j}=b_{j}^{1} ; \quad \mathrm{j}=1,2, \ldots, \mathrm{m} \\
& b_{j}=b_{j-n}^{2}-b_{j-n}^{1} ; \mathrm{j}=\mathrm{n}+1, \mathrm{n}+2, . .2 \mathrm{n} \\
& b_{2 n+j}=\sum_{i=1}^{m} a_{i}^{2}-\sum_{j=1}^{n} b_{j}^{1}
\end{aligned}
$$

Keterangan:

$\mathrm{a}_{i} \quad$ nilai supply di sumber $i$

$\mathrm{b}_{j}$ nilai demand di tujuan $\mathrm{j}$

4. Koefisien biaya $\mathrm{d}_{i j}$ didefenisikan dalam langkah-langkah berikut:

$$
\begin{aligned}
& d_{i j}=c_{i j}, i=1, . ., m, j=1, . ., n \\
& d_{i j}=c_{i-m, j}, i=m+1, . ., 2 m, j=1, . . n \\
& d_{i j}=c_{i, j-n}, i=1, . . m, j=n+1, . .2 n, \\
& d_{i j}=c_{i-m, j-n}, i=m+1, \ldots, 2 m, j=n+1, \ldots 2 n \\
& d_{i, 2 n+1} \text { adalah bilangan besar untuk i=1,...m }
\end{aligned}
$$

Algoritma yang digunakan dalam proses pengambilan keputusan adalah algoritma fuzzy integer transportation adalah sebagai berikut:

Langkah 1: Tetapkan nilai interval parameter $\lambda$, yaitu $\lambda(1):=0, \lambda(2):=1$

Langkah 2: Selesaikan masalah interval transportasi yang mengikuti kaidah (9) untuk $\lambda=\lambda_{1}$. Jika masalah tersebut feasible dan 
$c(x(\lambda(1))) \in G^{\lambda(1)}, \quad$ maka lanjutkan ke langkah 3. Namun bila tidak maka berhenti, masalah (1) adalah infeasible, dimana $\mu_{D}(x)=0$ untuk semua $x$.

Langkah 3: Selesaikan masalah interval transportasi yang mengikuti kaidah (9) untuk $\lambda=\lambda_{2}$. Jika masalah ini feasible dan $c(x(\lambda(2))) \in G^{\lambda(2)}$ maka berhenti, sehingga $x(\lambda(2))$ adalah solusi optimal dari masalah (1) dan $\mu_{D}(x(\lambda(2)))=1$, jika tidak maka lanjut ke langkah 4.

Langkah 4: Tetapkan $\lambda(1 / 2):=(\lambda(1)+\lambda(2)) / 2$ dan lanjutkan ke langkah 5

Langkah 5: Selesaikan masalah interval transportasi yang mengikuti kaidah (9) untuk $\lambda=\lambda(1 / 2)$. Jika masalah ini infeasible, tetapkan $\lambda(2):=\lambda(1 / 2)$ dan lanjutkan ke langkah 6. Jika hasilnya feasible dan $\left.c(x(\lambda(1))) \in G^{\lambda(1 / 2)}\right)$, maka ada tiga kemungkinan:

a. $\mu_{G}(x(\lambda(1 / 2)))=\mu_{c}(x(\lambda(1 / 2)))$, maka $x(\lambda(1 / 2))$ adalah solusi optimal dari masalah (1). Berhenti.

b. $\mu_{G}(x(\lambda(1 / 2)))>\mu_{c}(x(\lambda(1 / 2)))$, maka tetapkan $\lambda(1):=\mu_{c}(x(\lambda(1 / 2)))$, lanjut ke langkah 6

c. $\mu_{G}(x(\lambda(1 / 2)))<\mu_{c}(x(\lambda(1 / 2)))$, maka tetapkan $\lambda(2):=\mu_{c}(x(\lambda(1 / 2)))$, kemudian $\lambda(2):=\lambda(1 / 2)$, lanjut ke langkah 6

Langkah 6: Jika $\lambda(2)-\lambda(1)>\varepsilon$, kembali ke 4 . Jika tidak, periksalah apakah masalah (9) untuk $\lambda=\lambda_{1}$ adalah minimal extension dari masalah interval transportasi (9) untuk $\lambda=\lambda_{2}$. Jika tidak, kembali ke langkah 4. Jika sebaliknya maka berhenti - satu dari solusi $x(\lambda(1))$ atau $x(\lambda(2))$ adalah solusi optimal dari masalah transportasi fuzzy (1). Jika masalah (8) adalah infeasible untuk $\lambda=\lambda(2)$ maka $x(\lambda(1))$ adalah solusi optimal untuk masalah (1).

\subsection{IMPLEMENTASI MODEL}

Misalnya sebuah institusi PDAM akan memanajemen distribusi air yang berasal dari 2 sumber air menuju 2 tujuan distribusi. Sumber air yang terlibat adalah sumur dalam utara dengan supply air minimum sebanyak $5 \mathrm{~m} 3$, supply ratarata setahun sebanyak $10 \mathrm{~m} 3$ dan supply air maksimum selama setahun adalah $15 \mathrm{~m} 3$, kemudian sumur dalam selatan dengan supply air minimum sebanyak $10 \mathrm{~m} 3$, supply rata-rata setahun sebanyak $16 \mathrm{~m} 3$ dan supply air maksimum selama setahun adalah $22 \mathrm{~m} 3$. Terdapat 2 tujuan distribusi yakni kecamatan Banjarsari dengan demand air minimum sebanyak $8 \mathrm{~m} 3$ dan demand rata-rata setahun sebanyak $14 \mathrm{~m} 3$ dan demand air maksimum selama setahun adalah $20 \mathrm{~m} 3$, dan kecamatan Jebres dengan demand air minimum sebanyak 6 $\mathrm{m} 3$ dan demand rata-rata setahun sebanyak 10 $\mathrm{m} 3$ dan demand air maksimum selama setahun adalah $14 \mathrm{~m} 3$. Adapun biaya transmisi \& distribusi per unit dari sumber air ke tujuan distribusi adalah:

Tabel 1 Biaya transmisi \& distribusi

\begin{tabular}{|l|r|r|}
\hline \multirow{2}{*}{ Sumber } & \multicolumn{3}{|c|}{ Tujuan } \\
\cline { 2 - 3 } & Banjarsari & Jebres \\
\hline Sumur Dalam Utara & 12 & 20 \\
\hline Sumur Dalam Selatan & 25 & 40 \\
\hline
\end{tabular}

Proses perhitungan secara manual yang dilakukan sistem untuk memberikan alternatif keputusan adalah sebagai berikut :

1. Pembentukan Fuzzy Integer Transportation yang mengikuti persamaan (1) dimana parameter $c_{i j}$ diambil dari biaya transmisi \& distribusi pada tabel 1 sehingga menjadi: Meminimumkan $c(x)$

$$
c(x)=12 x_{11}+20 x_{12}+25 x_{21}+40 c_{22}
$$

2. Representasikan batasan melalui pendekatan fuzzy dengan cara membentuk bilangan fuzzy supply dan fuzzy demand dari data-data sumber air dan data-data tujuan dengan memakai kaidah (2). Sehingga dari data 
sumur dalam utara diperoleh bilangan fuzzy supply $A_{1}=(10,10,5,5)$, kemudian bilangan fuzzy supply dari data sumur dalam selatan $A_{2}=(16,16,6,6)$. Adapun pembentukan bilangan fuzzy demand untuk kecamatan Banjarsari $B_{1}=(14,14,6,6)$ dan bilangan fuzzy demand untuk kecamatan Jebres $B_{2}=$ $(10,10,4,4)$.

3. Sesuai kaidah (1), maka diperoleh persamaan untuk variabel batasan yakni berikut ini:

$$
\begin{aligned}
& x_{11}+x_{12} \cong(10,10,5,5)_{\mathrm{L}-\mathrm{L}} \\
& x_{21}+x_{22} \cong(16,16,6,6)_{\mathrm{L}-\mathrm{L}} \\
& x_{11}+x_{21} \cong(14,14,6,6)_{\mathrm{L}-\mathrm{L}} \\
& x_{12}+x_{22} \cong(10,10,4,4)_{\mathrm{L}-\mathrm{L}}
\end{aligned}
$$

4. Representasikan fungsi tujuan dengan pendekatan fuzzy yang mengikuti kaedah (3), sehingga diperoleh bilangan fuzzy goal $G=(0,300,0,150)$

5. Pembentukan $\lambda$-cut untuk nilai fuzzy supply, fuzzy demand dan fuzzy goal sesuai kaidah (6) dan (7) adalah:

$$
\begin{aligned}
A_{1}^{\lambda} & =[10-5(1-\lambda), 10+5(1-\lambda)] ; \\
A_{2}^{\lambda} & =[16-6(1-\lambda), 16+6(1-\lambda)] ; \\
B_{1}^{\lambda} & =[14-6(1-\lambda), 14+6(1-\lambda)] ; \\
B_{2}^{\lambda} & =[10-4(1-\lambda), 10+4(1-\lambda)] ; \\
G^{\lambda} & =[0,300+150(1-\lambda)] ;
\end{aligned}
$$

6. Mencari solusi dengan menggunakan algoritma fuzzy integer transportation :

Langkah 1:

Inisialisasi nilai $\lambda$-cut : $\lambda(1)=0$ dan $\lambda(2)=1$ Langkah 2:

\# Kerjakan nomor 5 untuk $\lambda=\lambda(1)=0$

$A_{1}^{0}=[10-5(1-0), 10+5(1-0)]=[5,15] \rightarrow$

$a_{1}^{1}=5, a_{1}^{2}=15$

$A_{2}^{0}=[16-6(1-0), 16+6(1-0)]=[10,22]$

$\rightarrow a_{2}^{1}=10, a_{2}^{2}=22$

$B_{1}^{0}=[14-6(1-0), 14+6(1-0)]=[8,20] \rightarrow b_{1}^{1}=$

$8, \quad b_{1}^{2}=20$

$B_{2}^{0}=[10-4(1-0), 10+4(1-0)]=[6,14] \rightarrow b_{2}^{1}=$

$6, b_{2}^{2}=14$

$G^{0}=[0,300+150(1-0)]=[0,450]$
Representasikan masalah fuzzy transportasi dengan tabel 2.

Tabel 2 Tabel awal masalah transportasi untuk

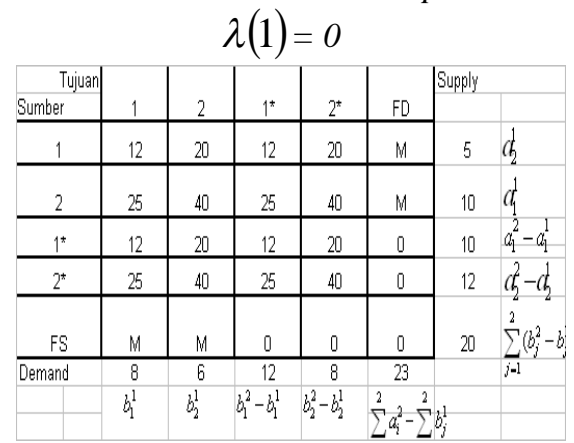

Selesaikan tabel transportasi dengan VAM menggunakan tabel matrik transportasi (Tabel 3) diperoleh: Total $\mathrm{z}=(25)+1(40)+1(25)+5(20)+10(0)+$ $12(0)+1(0)+11(0)+8(0)+1(0)$

Maka $\mathrm{z}=365 \in[0,450] \rightarrow$ Feasible

Tabel 3 Tabel matrik masalah transportasi untuk $\lambda(1)=0$

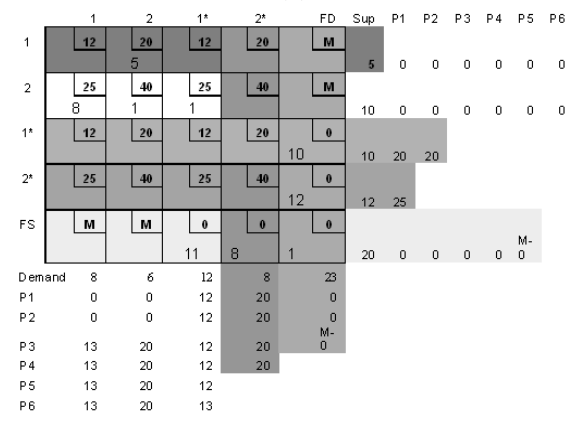

Hasilnya feasible, lanjut ke langkah 3.

Langkah 3:

$\$$ Kerjakan nomor 5 untuk $\lambda=\lambda(2)=1$

$A_{1}^{1}=[10-5(1-1), 10+5(1-1)]=[10,10] \rightarrow a_{1}^{1}=10, a_{1}^{2}=10$

$A_{2}^{1}=[16-6(1-1), 16+6(1-1)]=[16,16]$

$B_{1}^{1}=[14-6(1-1), 14+6(1-1)]=[14,14]$

$B_{2}^{1}=[10-4(1-1), 10+4(1-1)]=[10,10]$

$G^{1}=[0,300+150(1-1)]=[0,300]$

dengan VAM menggunakan tabel matrik transportasi . Diperoleh: Total $\mathrm{z}=14(25)+$ $0(40)+10(20)+2(\mathrm{M})$

Maka $\mathrm{z}=550+2 \mathrm{M} \notin[0,300] \rightarrow$ Infeasible, lanjut ke langkah 4.

Langkah 4:

$\lambda(1 / 2):=(\lambda(1)+\lambda(2)) / 2=(0+1) / 2=0,5$ lanjutkan ke langkah 5

Langkah 5: 
Kerjakan nomor 5 untuk $\lambda=\lambda(1 / 2)=0,5$

$A_{1}^{0,5}=[10-5(1-0,5), 10+5(1-0,5)]=[7,5 ; 12,5]=[8,12]$

$A_{2}^{0,5}=[16-6(1-0,5), 16+6(1-0,5)]=[13,19]$

$B_{1}^{0,5}=[14-6(1-0,5), 14+6(1-0,5)]=[11,17]$

$B_{2}^{0,5}=[10-4(1-0,5), 10+4(1-0,5)]=[8,12]$

$G^{0,5}=[0,300+150(1-0,5)]=[0,375]$

Nilai bilangan fuzzy $A_{1}^{0,5}=[7,5 ; 12,5]$ berbentuk bilangan real, maka harus dibawa ke bentuk bilangan integer dengan melakukan pembulatan nilai. Untuk nilai batas bawah dari bilangan fuzzy dibulatkan ke atas dan nilai batas atas bilangan fuzzy dibulatkan ke bawah, sehingga bilangan fuzzy $A_{1}^{0,5}=[8,12]$.

Selesaikan tabel transportasi dengan VAM :

Total $\mathrm{z}=$ $2(25)+8(20)+4(0)+4(0)+2(0)+6(0)+4(0)$

Maka $\mathrm{z}=485 \notin[0,450] \rightarrow$ infeasible, lanjut ke langkah 6 Tetapkan $\lambda(2)=\lambda(1 / 2)=0,5$

Langkah 6:

$\lambda(2)-\lambda(1)>\varepsilon$, tetapkan $\varepsilon=0,07$

$0,5-0=0,5>0,07$ maka kembali ke langkah 4 lagi

Langkah 4:

$\lambda(1 / 2):=(\lambda(1)+\lambda(2)) / 2=(0+0,5) / 2=0,25$

Langkah 5:

Kerjakan nomor 5 untuk $\lambda=\lambda(1 / 2)=0,25$ $A_{1}^{0,25}=[10-5(1-0,25), 10+5(1-0,25)]=[6,25 ; 13,75]=[7,13]$ $A_{2}^{0,25}=[16-6(1-0,25), 16+6(1-0,25)]=[11,5 ; 20,5]=[12,20]$ $B_{1}^{0,25}=[14-6(1-0,25), 14+6(1-0,25)]=[9,5 ; 18,5]=[10,18]$

$B_{2}^{0,25}=[10-4(1-0,25), 10+4(1-0,25)]=[7,13]$ $G^{0,25}=[0,300+150(1-0,25)]=[0 ; 412,5]=[0,412]$

Selesaikan tabel transportasi dengan VAM :

Totalz $=10(25)+7(20)+2(25)+6(0)+6(0)+2(0)+8(0)+6(0)$

Maka $\mathrm{z}=440 \notin[0,412] \rightarrow$ infeasible, sehingga lanjut ke langkah 6 Sehingga

$\lambda(2)=\lambda(1 / 2)=0,25$

Langkah 6:

$\lambda(2)-\lambda(1)>\varepsilon$, tetapkan $\varepsilon=0,07$

$0,25-0=0,25>0,07$ maka kembali ke langkah 4 lagi

Langkah 4:

$$
\lambda(1 / 2):=(\lambda(1)+\lambda(2)) / 2=(0+0,25) / 2=0,125
$$

Langkah 5:

$\$ \quad$ Kerjakan nomor 5 untuk $\lambda=\lambda(1 / 2)=0,125$
$A_{1}^{0,125}=[10-5(1-0,125), 10+5(1-0,125)]=[5,625 ; 14,375]=[6,14]$

$A_{2}^{0,125}=[16-6(1-0,125), 16+6(1-0,125)]=[10,75 ; 21,25]=[11,21]$

$B_{1}^{0,125}=[14-6(1-0,125), 14+6(1-0,125)]=[8,75 ; 19,25]=[9,19]$

$B_{2}^{0,125}=[10-4(1-0,125), 10+4(1-0,125)]=[6,5 ; 13,5]=[7,13]$

$G^{0,125}=[0,300+150(1-0,125)]=[0 ; 431,3]=[0,431]$

Total biaya distribusi $\mathrm{z}=9(25)+6(20)+1(40)+1(25)+9$ $(0)+6(0)+1(0)+8(0)+10(0)$

Maka $\mathrm{z}=410 \in[0,431] \rightarrow$ feasible

Total nilai variabel keputusan $x$ :

$x_{11}=x_{11}+x_{11^{*}}+x_{1 * 1}+x_{1 * 1 *}=0+0+0+0=0$

$x_{12}=x_{12}+x_{12 *}+x_{1 * 2}+x_{1 * 2 *}=6+0+0+0=6$

$x_{21}=x_{21}+x_{21^{*}}+x_{2 * 1}+x_{2 * 1 *}=9+1+0+0=$

$10 x_{22}=x_{22}+x_{22 *}+x_{2 * 2}+x_{2 * 2 *}=1+0+0+0=$

1

Total nilai supply $A_{i}$ dan demand $B_{j}$ :

$$
\begin{aligned}
& A_{1}=x_{11}+x_{12}=0+6=6 \\
& A_{2}=x_{21}+x_{22}=10+1=11 \\
& B_{1}=x_{11}+x_{21}=0+10=10 \\
& B_{2}=x_{12}+x_{22}=6+1=7
\end{aligned}
$$

Nilai derajat keanggotaan untuk supply $\mu_{A i}[x]$ dan demand $\mu_{B j}[x]$ adalah:

$$
\begin{aligned}
& \mu_{A 1}[x]=1-(10-6) / 5=0,2 \\
& \mu_{A 2}[x]=1-(16-11) / 6=0,167 \\
& \mu_{B 1}[x]=1-(14-10) / 6=0,333 \\
& \mu_{B 2}[x]=1-(10-7) / 4=0,25
\end{aligned}
$$

Nilai derajat kecocokan batasan $\mu_{C}[x]$ untuk fuzzy integer transportation problem sesuai dengan kaidah (3.29) adalah $\mu_{C}[x]=$ $\min \{0,2 ; 0,167 ; 0,333 ; 0,25\}=0,167$

\& Nilai derajat kecocokan goal $\mu_{G}[x]$ fuzzy integer transportation problem sesuai dengan kaidah (3.29) adalah $\mu_{G}[x]=1-(410-300) / 150$ $=0,267$

Sesuai dengan algoritma ke 5.b, jika nilai $\mu_{G}(x(\lambda(1 / 2)))>\mu_{c}(x(\lambda(1 / 2)))$, maka tetapkan $\lambda(1):=\mu_{c}(x(\lambda(1 / 2)))$. Sehingga jika $\mu_{G}[x]>$ $\mu_{C}[x]$ maka $\lambda(1)=\mu_{C}[x]=0,167$

\& Berdasarkan kaedah (3.28) pada defenisi 2 maka derajat keanggotaan solusi maksimum: $\mu_{D}[x]=\min \left\{\mu_{G}[x] ; \mu_{C}[x]\right\}=\min (0,267 ; 0,167\}$ $=0,167$

Langkah 6: 
$\lambda(2)-\lambda(1)>\varepsilon$, tetapkan $\varepsilon=0,07$

$0,25-0,167=0,083>0,07$ maka kembali ke

langkah 4 lagi

Langkah 4:

$\lambda(1 / 2):=(\lambda(1)+\lambda(2)) / 2=(0,167+0,25) / 2=0,2085$

Langkah 5:

Kerjakan nomor 5 untuk $\lambda=\lambda(1 / 2)=0,2085$ $A_{1}^{0,2085}=[10-5(1-0,2085), 10+5(1-0,2085)]=$ $[6,043 ; 13,958]=[7,13]$

$A_{2}^{0,2085}=[16-6(1-0,2085), \quad 16+6(1-0,2085)]=$ $[11,251 ; 20,749]=[12,20]$

$B_{1}^{0,2085}=[14-6(1-0,2085), 14+6(1-0,2085)]=$

$[9,251 ; 18,749]=[10,18]$

$B_{2}^{0,2085}=[10-4(1-0,2085), 10+4(1-0,2085)]=$

$[6,83 ; 13,17]=[7,13]$

$G^{0,2085}=[0,300+150(1-0,2085)]=[0 ; 418,73]=$ $[0,418]$

$\mathrm{Z}=10(25)+7(20)+2(25)+6(0)+6(0)+2(0)+8(0)+6(0)$

Maka $\mathrm{z}=440 \notin[0,418] \rightarrow$ infeasible, , sehingga

lanjut ke langkah 6 Sehingga $\lambda(2)=\lambda(1 / 2)=$ 0,2085

Langkah 6:

$\lambda(2)-\lambda(1)>\varepsilon$, tetapkan $\varepsilon=0,07$

$0,2085-0,167=0,0415<0,07$ maka terapkan kaedah pada defenisi 5, periksa apakah $\lambda=\lambda(1)=0,167$ adalah minimal ektension dari interval batasan (langkah 5) untuk $\lambda=\lambda(2)=$ 0,2085 .

Tentukan nilai $\mathrm{t}$ sebagai bilangan integer terdekat dari $A_{1}^{0,2085}=[7,13]$ tapi bukan anggota dari $A_{1}^{0,2085}$ yakni: 6 dan 14 , bilangan integer terdekat dari $A_{2}^{0,2085}=[12,20]$ tapi bukan anggota dari $A_{2}^{0,2085}$ yaitu 11 dan 21 , bilangan integer tergdekat dari $B_{1}^{0,2085}=$ $[10,18]$ tapi bukan anggota dari $B_{1}^{0,2085}$ yaitu 9 dan 19 dan bilangan integer terdekat $B_{2}^{0,2085}=$ [7,13] tapi bukan anggota dari $B_{2}^{0,2085}$ yaitu 6 dan 14.

Nilai derajat keanggotaan $\mu_{A i}[x]$ dan $\mu_{B j}[x]$ :

$\mu_{A 1}[6]=1-(10-6) / 5=0,20$

$\mu_{A 1}[14]=1-(14-10) / 5=0,20$

$\mu_{A 2}[11]=1-(16-11) / 6=0,167$

$\mu_{A 2}[21]=1-(21-16) / 6=0,167$

$$
\begin{array}{ll} 
& \mu_{B 1}[9]=1-(14-9) / 6=0,167 \\
& \mu_{B 1}[19]=1-(19-14) / 6=0,167 \\
8 & \mu_{B 2}[6]=1-(10-6) / 4=0,00 \\
& \mu_{B 2}[14]=1-(14-10) / 4=0,00
\end{array}
$$

\& Diperoleh $\quad \lambda=\lambda * \quad=\max$ $\{0,2 ; 0,2 ; 0,167 ; 0,167 ; 0,167 ; 0,167,0 ; 0\}=0,2$

$\neq$ Nilai $\lambda *=0,2 \neq \lambda=\lambda(1)$ sehingga $\lambda=\lambda(1)$ bukan minimal ekstension dari interval batasan (langkah 5) untuk $\lambda=\lambda(2)=0,2085$. Kembali ke langkah 4

Langkah 4:

$\lambda(1 / 2):=(\lambda(1)+\lambda(2)) / 2$

$=(0,167+0,2085) / 2=0,187$

Langkah 5:

$\neq$ Kerjakan nomor 5 untuk $\lambda=\lambda(1 / 2)=0,1878$ $A_{1}^{0,1878}=[10-5(1-0,1878), 10+5(1-0,1878)]=[6,14]$ $A_{2}^{0,1878}=[16-6(1-0,1878), 16+6(1-0,1878)]=[12,20]$ $B_{1}^{0,1878}=[14-6(1-0,1878), 14+6(1-0,1878)]=[9,18]$ $B_{2}^{0,1878}=[10-4(1-0,1878), 10+4(1-0,1878)]=[7,13]$ $G^{0,1878}=[0,300+150(1-0,1878)]=[0,421]$

Selesaikan tabel transportasi dengan VAM:

Total $\mathrm{z}=9(25)+6(20)+2(25)+1(40)+7(0)+6(0)+2(0)$ $+8(0)+8(0)$

Maka $\mathrm{z}=435 \notin[0,421] \quad \rightarrow$ infeasible, sehingga lanjut ke langkah 6 Sehingga $\lambda(2)=\lambda(1 / 2)=0,1878$

Langkah 6:

$\lambda(2)-\lambda(1)>\varepsilon$, tetapkan $\varepsilon=0,07$

$0,1878-0,167=0,021<0,07$; maka terapkan kaedah pada defenisi 5, periksa apakah $\lambda=\lambda(1)=0,167$ adalah minimal ektension dari interval batasan (langkah 5) untuk $\lambda=\lambda(2)=$ 0,1878 .

\# Tentukan nilai t sebagai bilangan integer terdekat dari $A_{1}^{0,1878}=[6,14]$ tapi bukan anggota dari $A_{1}^{0,1878}$ yakni: 5 dan 15 , bilangan integer terdekat dari $A_{2}^{0,1878}=[12,20]$ tapi bukan anggota dari $A_{2}^{0,1878}$ yaitu 11 dan 21, bilangan integer tergdekat dari $B_{1}^{0,1878}=$ $[9,18]$ tapi bukan anggota dari $B_{1}^{0,1878}$ yaitu 8 dan 19 dan bilangan integer terdekat $B_{2}^{0,1878}=$ $[7,13]$ tapi bukan anggota dari $B_{2}^{0,1878}$ yaitu 6 dan 14.

$\neq$ Nilai derajat keanggotaan $\mu_{A i}[x]$ dan $\mu_{B j}[x]$ : 


$$
\begin{aligned}
& \mu_{A 1}[5]=1-(10-5) / 5=0,0 \\
& \mu_{A 1}[15]=1-(15-10) / 5=0,0 \\
& \mu_{A 2}[11]=1-(16-11) / 6=0,167 \\
& \mu_{A 2}[21]=1-(21-16) / 6=0,167 \\
& \mu_{B 1}[8]=1-(14-8) / 6=0,0 \\
& \mu_{B 1}[19]=1-(19-14) / 6=0,167 \\
& \mu_{B 2}[6]=1-(10-6) / 4=0,00 \\
& \mu_{B 2}[14]=1-(14-10) / 4=0,00
\end{aligned}
$$

Diperoleh

$$
\lambda=\lambda *
$$$$
\{0,0 ; 0,0 ; 0,167 ; 0,167 ; 0,0 ; 0,167 ; 0 ; 0 ; 0,0\}=
$$
0,167

Nilai

$$
\lambda *=0,167=\lambda=\lambda(1) \quad \text { sehingga }
$$

$\lambda=\lambda(1)$ adalah minimal ekstension dari interval batasan (langkah 5) untuk $\lambda=\lambda(2)=0,1878$.

Oleh karena itu $x(\lambda(1))=0,167$ atau $x(\lambda(2))=0,1878$; salah satunya merupakan solusi optimal. Nilai $\mu_{D}[x]$ yang terbesarlah yang lebih baik. Sehingga $\mu_{D}\left[\mathrm{x}\left(\lambda_{1}=0,167\right)\right]=0,167$ menjadi solusi optimal.

Hasil akhir:

$$
\mu_{D}[\mathrm{x}]=0,167
$$

Total biaya distribusi $c(x)=$ Rp. 410,00

Total air yang didistribusikan dari tiap sumber ke tiap tujuan $\left(x_{i j}\right)$

oDari Sumur dalam utara ke Banjarsari $\left(x_{11}\right)=$ $0 \mathrm{~m} 3$

oDari Sumur dalam utara ke Jebres $\left(x_{12}\right)=6$ $\mathrm{m} 3$

oDari Sumur dalam selatan ke Banjarsari $\left(x_{21}\right)=10 \mathrm{~m} 3$

oDari Sumur dalam utara ke Jebres $\left(x_{22}\right)=1$ $\mathrm{m} 3$

\subsection{IMPLEMENTASI SISTEM}

Aplikasi sistem terdiri atas tiga bagian utama yakni antarmuka manajemen data, antarmuka manajemen model dan antarmuka pengambilan keputusan. Fungsi antarmuka manajemen data adalah pengelolaan data-data internal untuk kemudian disimpan dalam basis data, lihat gambar 3. Fungsi antarmuka manajemen model adalah untuk mengatur domain bilangan fuzzy dan membentuk fungsi keanggotaan fuzzy, ditunjukkan gambar 4. Fungsi antarmuka pengambilan keputusan adalah memberikan bantuan bagi pengambil keputusan untuk membuat keputusan berdasarkan analisa yang diberikan sistem, dimana pihak pengambil keputusan bebas dalam memilih kriteria penilaian dalam pengambilan keputusan, seperti yang diperlihatkan gambar 5 .

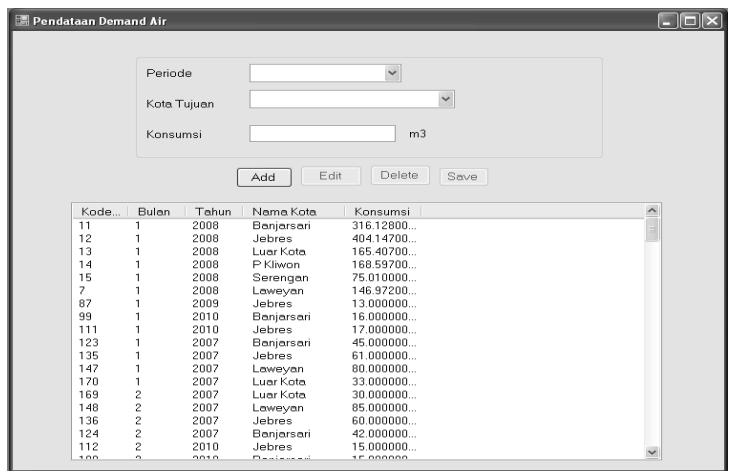

Gambar 3 Antarmuka manajemen data

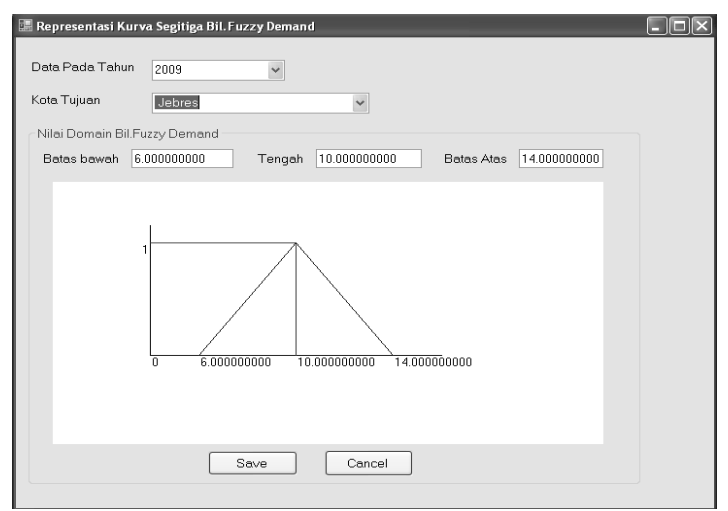

Gambar 4 Antarmuka manajemen model

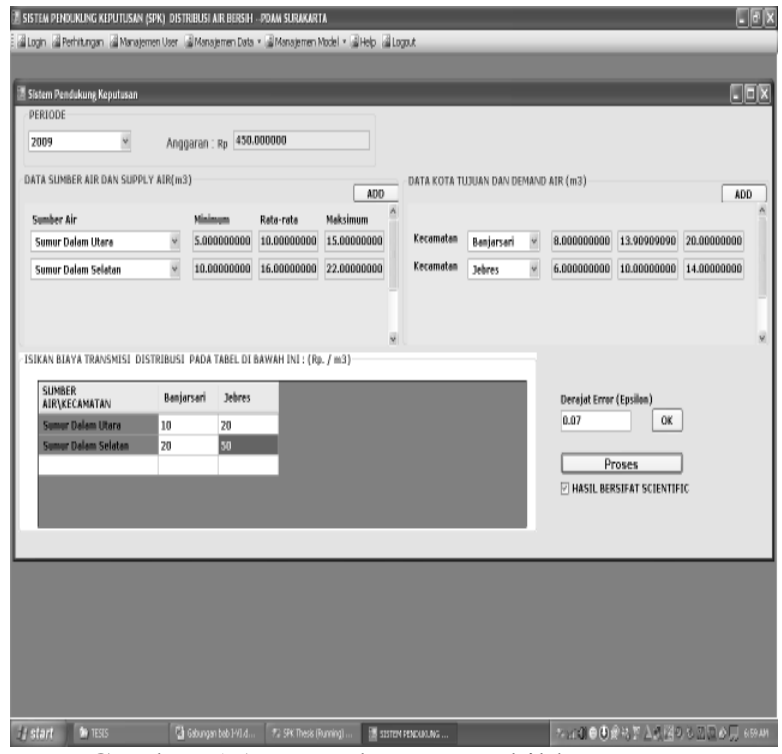

Gambar 5 Antarmuka pengambil keputusan 


\section{Hasil Pengujian Dan Pembahasan}

Terdapat 3 skenario pengujian sistem, diperoleh hasil pengujian pada tabel 4 .

Tabel 4 Hasil pengujian

\begin{tabular}{|l|r|r|r|}
\hline Tahap uji & Iterasi ke- & Nilai Lamda & \multicolumn{1}{c|}{ Total Z } \\
\hline Data ke-1 & 1 & 0 & 331.00 \\
\hline & 2 & 1 & 460.00 \\
\hline & 3 & 0.5 & 420.00 \\
\hline & 4 & 0.25 & 380.00 \\
\hline & 5 & 0.375 & 430.00 \\
\hline & 6 & 0.3125 & 410.00 \\
\hline Data ke-2 & 1 & & 380.00 \\
\hline & 2 & 0 & 740.00 \\
\hline & 3 & 1 & 570.00 \\
\hline & 4 & 0.5 & 490.00 \\
\hline & 5 & 0.25 & 540.00 \\
\hline & 6 & 0.4375 & 570.00 \\
\hline & 7 & 0.4062 & 570.00 \\
\hline & 8 & 0.3906 & 560.00 \\
\hline & 9 & 0.375 & 540.00 \\
\hline & & & $21,050.00$ \\
\hline Data ke-3 & 1 & 0 & $27,150.00$ \\
\hline & 2 & 1 & $24,105.00$ \\
\hline & 3 & 0.5 & $22,645.00$ \\
\hline & 4 & 0.25 & $22,645.00$ \\
\hline & 5 & 0.25 & $22,645.00$ \\
\hline & 6 & 0.25 & $22,645.00$ \\
\hline & 7 & 0.25 & $22,645.00$ \\
\hline
\end{tabular}

Rincian hasil-hasil pengujian adalah sebagai berikut:

1. Pada pengujian pertama dengan menggunakan transportasi klasik $(\lambda=1)$, total biaya distribusi (z) yang harus dikeluarkan mencapai Rp 460,00 melebihi anggaran dana transmisi dan distribusi instansi yang hanya bisa menyediakan dana maksimal Rp 450,00. Sekalipun melalui dana sebesar itu, air yang disalurkan ke pelanggan telah memenuhi kebutuhan air pelanggan yakni sebanyak 10 m3 dari Sumur Dalam Utara dan sebanyak 16 m3 dari Sumur Dalam Selatan, namun total biaya distribusi yang diperoleh tidak memenuhi goal sistem. Jika menggunakan Fuzzy Integer Transportation $(\lambda=0,3125)$, total biaya distribusi (z) yang harus dikeluarkan hanya sebesar Rp 410,00; biaya distribusi ini lebih hemat jika dibandingkan dengan pendekatan model Transportasi klasik, dengan selisih sebesar Rp 40,00. Biaya distribusi tersebut dapat dipenuhi anggaran dana PDAM-Surakarta dimana dana cadangan terpakai sebanyak Rp. 110,00. Adapun derajat kecocokan goal $\mu_{G}(x)$ adalah sebesar 0,2667. usulan alokasi air bersih yang mendekati harapan kebutuhan pelanggan, adalah kebutuhan air di kecamatan Banjarsari dapat dipenuhi sebanyak $11 \mathrm{~m} 3$, total air yang dikirimkan ini berada dalam range demand air, dimana air di supply dari Sumur dalam selatan sebesar
11 m3. Dan kebutuhan air di kecamatan Jebres dapat dipenuhi sebanyak $8 \mathrm{~m} 3$ yang di-supplay dari Sumur Dalam Utara sebesar 7 m3 dan dari Sumur dalam selatan sebesar 1 $\mathrm{m} 3$.

2. Pada pengujian kedua, dengan menggunakan model Transportasi klasik $(\lambda=1)$ total biaya distribusi yang harus dikeluarkan mencapai Rp 710,00 melebihi anggaran dana instansi yang hanya bisa menyediakan dana maksimal Rp 700,00. Dimana air yang disalurkan ke pelanggan sebesar $12 \mathrm{~m} 3$ dari Sumur dalam utara dan sebanyak $8 \mathrm{~m} 3$ dari Sumur dalam selatan serta IPA jurug sebesar $10 \mathrm{~m} 3$. Dengan pendekatan Fuzzy Integer Transportation $(\lambda=0,375)$, diperoleh hasil yang lebih baik dimana dimana total biaya distrijbusi yang harus dikeluarkan hanya sebesar Rp 540,00; biaya ini lebih rendah jika dibandingkan dengan model Transportasi klasik dengan selisih sebesar Rp 170,00. Biaya distribusi ini dapat dipenuhi anggaran dana instansi dimana dana cadangan terpakai sebanyak Rp. 240,00. Usulan alokasi air bersih yang mendekati harapan demand pelanggan, adalah total air yang didistribusikan ke kecamatan Banjarsari adalah $13 \mathrm{~m} 3$, kebutuhan ini dipenuhi dari Sumur dalam utara sebanyak $7 \mathrm{~m} 3$ dan Sumur dalam selatan sebanyak 6 m3. Kemudian, total air yang didistribusikan ke kecamatan Jebres sebanyak $10 \mathrm{~m} 3$, kebutuhan ini dipenuhi dari Sumur dalam selatan sebanyak $3 \mathrm{~m} 3$ dan IPA Jurug sebanyak $7 \mathrm{~m} 3$.

3. Pada pengujian ketiga, dapat dilihat bahwa dengan menggunakan Transportasi Klasik $(\lambda=1)$ total biaya distribusi yang harus dikeluarkan mencapai Rp 27.150,00 melebihi anggaran dana PDAM-Surakarta yang hanya bisa menyediakan dana maksimal $\mathrm{Rp}$ $25.000,00$. Dengan biaya sebesar itu, air yang didistribusikan dapat memenuhi pelanggan yakni sebesar $50 \mathrm{~m} 3$ dari Sumur Dalam Utara, sebanyak $70 \mathrm{~m} 3$ dari Sumur Dalam Selatan dan dari IPA Jurug sebanyak $80 \mathrm{~m} 3$. Dengan menggunakan Fuzzy Integer Transportation, diperoleh hasil distribusi yakni total air yang didistribusikan ke kecamatan Banjarsari adalah $43.000 \mathrm{~m} 3$, kebutuhan ini dipenuhi dari IPA Jurug sebanyak $43.000 \mathrm{~m} 3$. Kemudian, total air yang didistribusikan ke kecamatan Jebres sebanyak $53.000 \mathrm{~m} 3$, kebutuhan ini dipenuhi 
dari Sumur dalam utara sebanyak $32.000 \mathrm{~m} 3$ dan dari Sumur dalam selatan sebanyak $21.000 \mathrm{~m} 3$. Total air yang didistribusikan ke kecamatan Laweyan adalah $65.000 \mathrm{~m} 3$ yang berasal dari Sumur dalam selatan sebanyak $50.000 \mathrm{~m} 3$ dan IPA Jurug sebanyak 15.000 $\mathrm{m} 3$. Total air yang didistribusikan ke luar kota adalah $27.000 \mathrm{~m} 3$ yang disalurkan dari IPA Jurug sebanyak $27.000 \mathrm{~m} 3$. Dan total biaya distribusi yang diperoleh adalah $\mathrm{Rp}$. 22.645,00. SPK Distribusi Air Bersih dengan model Fuzzy Integer Transportation, memberikan usulan alokasi air bersih yang tidak mendekati harapan demand pelanggan, sehingga tidak dapat memenuhi kebutuhan air pelanggannamun. Oleh karena itu solusi maksimum tidak didapatkan, hal ini diketahui dari derajat kecocokan solusi maksimum $\mu_{D}(x)$ yang bernilai 0 .

\section{KESIMPULAN}

Adapun kesimpulan penilitian yang dapat ditarik adalah:

1. Penggunaan metode VAM sebagai metode solusi basis awal, dapat memberikan pemecahan bagi hasil total biaya distribusi (z) yang feasible.

2. Penyelesaian masalah distribusi dengan pendekatan model fuzzy integer transportation menunjukkan hasil yang lebih lebih baik, yakni total biaya distribusi yang minimum dengan total air yang didistribusikan mendekati harapan pelanggan, dibandingkan dengan pendekatan model transportasi klasik.

Untuk pengembangan sistem lebih lanjut, sebaiknya penentuan distribusi air bersih yang baik tidak hanya dilihat dari aspek biaya distribusi tapi juga dari multi aspek seperti waktu, operasi dan produksi.

\section{REFERENSI}

[1] Undang-Undang No 55 tahun 1962 tentang Perusahaan Daerah

[2] Wulan, S.I.A., 2005, Kualitas Air Bersih Untuk Pemenuhan Kebutuhan Rumah Tangga Di Desa Pasarean Kecamatan Adiwerna Kabupaten Tegal, Skripsi, Jurusan Geografi Fakultas Ilmu Sosial, Universitas Negeri Semarang, Semarang.

[3] Turban, E., Jay, E. A., 2001, Decision Support Systems and Intelligent Systems $-6^{\text {th }}$ Ed., Prentice Hall, New Jersey.

[4] Raman, H., Mohan, S., Sethuraj, G., 1994, A Knowledge Based Decision Support System for Water Distribution Management, Transactions on Information and
Communication Technologies Volume 6, hal 157-163, WIT Press, India.

[5] Soehadi, G., 2006, Penggunaan algoritma Genetika Dalam Sistem Pendukung Keputusan Untuk Optimisasi Penyaluran Air Irigasi, Prosiding Semiloka Teknologi Simulasi dan Komputasi serta Aplikasi, hal 155-163, http://komputasi.inn.bppt.go.id/semiloka06/Gani_Soehadi.p df, diakses 12 Oktober 2009.

[6] Ozceylan, E., 2010, A Decision Support System to Compare the Transportation Modes in Logistic, International Journal of Lean Thinking Volume 1, Issue, hal 59-83,

http://www.thinkinglean.com/articles/vol1/010701m.pdf, diakses 5 Desember 2010.

[7] Shih, L.H., 1999, Cement Transportation Planning via Fuzzy Linier Programming, International Journal of Produstion Economics vol 58, hal 277-287

[8] Liang, T.F., 2006, Distribution planning decisions using interactive fuzzy multi-objective linear programming, Fuzzy Set and System Volume 157, hal 1303-1316

[9] Buckley, J.J., Jowers, J.L., 2008, Fuzzy Transportation Problem-Monte Carlo Method in Fuzzy Optimization, Studies in Fuzziness and Soft Computing Volume 222, hal 217-221

[10] Nunkaew, W., Phruksaphanrat, B., 2009, A Multiobjective Programming for Transportation Problem with The Consideration of Both Depot to Customer and Customer Relationship, Proceedings of the International MultiConference of Engineers and Computer Scientists Vol II, IMECS, hal 1-6.

[11] Arifin, A., 2011, Implementasi Fuzzy Integer Transportation pada Sistem Pendukung Keputusan untuk Distribusi Air Bersih (Studi Kasus di PDAM Surakarta), Tesis, Jurusan Ilmu Komputer Fakultas MIPA, Universitas Gajah Mada.

[12] Chanas, S., Kuchta, D., 1998, Fuzzy Integer Transportation Problem, Fuzzy Set and System 98, hal 291-298 